\title{
IDENTIFIKASI TINGKAT KONDISI FISIK ATLET RENANG PUSLATKOT KONI KOTA KEDIRI MENGHADAPI PORPROV 2022
}

\author{
Septyaning Lusianti \\ Universitas Nusantara PGRI Kediri \\ E-mail: lusi.septya@unpkdr.ac.id \\ DOI: https://doi.org/10.36526/kejaora.v6i1.1280
}

\begin{abstract}
ABSTRAK
Renang merupakan salah satu cabang olahraga yang membutuhkan optimalisasi kondisi fisik secara menyeluruh. Terdapat beberapa indikator yang sangat perlu diperhatikan yaitu tingkat kekuatan otot tungkai dan tingkat VO2Max. Penelitian ini bertujuan untuk mengetahui tingkat kekuatan otot tungkai dan daya tahan VO2Max pada atlet renang PUSLATKOT Kediri. Metode pengumpulan data yang digunaka yaitu dengan menggunakan teknik tes dan pengukuran, yaitu Multistage Fitness Tes (MFT) atau bleep test dan tes vertical jump.Berdasarkan analisis data hasil kekuatan otot tungkai dengan menggunakan instrumen tes vertical jump pada atlet PUSLATKOT cabang olahraga renang, dapat dikemukakan bahwa prosentase terbesar berada dalam kategori kurang dengan persentase $66,6 \%$ sejumlah 4 atlet. Sedangkan prosentase terbesar tingkat VO2Max berada dalam kategori sedang dengan persentase $50 \%$ dengan jumlah 3 atlet.
\end{abstract}

Kata Kunci: Kondisi Fisik, Daya Ledak Otot Tungkai, VO2Max, Renang

\section{PENDAHULUAN}

Pencapaian sebuah prestasi yang optimal merupakan suatu tuntutan yang akan selalu tertanam dalam jiwa seorang atlet. (Utami, 2015) mengemukakan prestasi optimal dalam olahraga dapat dicapai bila latihan diterapkan secara berkualitas, dan menganut konsep pembinaan pramida sebagai proses pencapaian tujuan. Untuk meraih prestasi tersebut, tentunya terdapat beberapa faktor yang harus selalu dipersiapkan dan dijaga oleh para atlet tersebut, salah satunya adalah kemampuan kondisi fisik. Sebagaimana pernyataan (A. T. Candra, 2016) bahwa perkembangan sebuah prestasi olahraga adalah hasil dari kombinasi kemampuan fisik, teknik, taktik, mental olahragawan. Kondisi fisik merupakansuatu hal yang cukup mendasar untuk menentukan suatu prestasi olahraga (Mulyadi \& Nikon, 2019). Kondisi fisik ditinjau dari segi faalnya adalah kemampuan seseorang dapat diketahui sampai sejauh mana kemampuanya sebagai pendukung aktivitas menjalankan olahraga (Wiwoho et al., 2014).

\begin{abstract}
Musrifin \& Bausad (2020) berpendapat kondisi fisik adalah kemampuan seseorang untuk memfungsikan organ-organ tubuh dalam melakukan segala aktivitas fisik dan satu kesatuan utuh dari komponen- komponen yang tidak bisa dipisahkan. Menurut Supriyoko \& Mahardika (2018) kondisi fisik merupakan hal mutlak yang wajib dimiliki oleh atlet di dalam mengembangkan dan meningkatkan prestasi olahraga yang optimal, sehingga segenap kondisi fisiknya harus dikembangkan dan ditingkatkan. Jika kondisi fisik kurang baik hasilnya juga akan kurang memuaskan, sebaliknya jika kondisi fisik prima maka hasilnya secara umum tentu baik (Lufisanto, 2014). Komponen fisik yang perlu diperhatikan untuk dikembangkan ada beberapa, diataranya adalah daya tahan kardiovaskuler, daya tahan kekuatan, kekuatan otot (strength), kelentukan (flexibility), kecepatan, stamina, kelincahan (agility), daya ledak otot (power),daya tahan kekuatan (strength endurance) (Junaidi, 2019).

Daya ledak (power) merupakan salah satu dari sepuluh komponen-komponen
\end{abstract}


Jurnal Kejaora: Jurnal Kesehatan Jasmani dan Olah Raga

ISSN: 2541-5042 (Online)

ISSN: 2503-2976 (Print)

Volume 6 Nomor 1, Edisi April 2021

kondisi fisik (Pengaruh Metode Latihan Dan Kekuatan Otot Tungkai Terhadap Power Otot Tungkai). Selaras pendapat Pramudani et al. (2018) bahwa salah satu indikator kebugaran fisik yaitu dari segi kemampuan daya ledak otot dan dapat diuji dengan menggunakan tes vertical jump. Dari berbagai cabang olahraga di atas, power tungkai memiliki peran penting untuk menentukan kemampuan atlit dalam meraih prestasi (Haryono \& Pribadi, 2012). Widyaratni et al. (2016) berpendapat salah satu faktor yang mempengaruhi vertical jump adalah fleksibilitas dan power otot tungkai. (Pramudani et al., 2018) berpendapat vertical Jump adalah sejenis gerakan yang sering terlihat dalam tes keterampilan olahraga, dan dibahas dalam studi terkait sebelumnya. Selain komponen kondisi fisik daya ledak tersebut, daya tahan pada juga merupakan salah satu komponen yang perlu diperhatikan pada atlet cabang olahraga renang.

Daya tahan merupakan kemampuan seseorang untuk melakukan aktifitas dengan waktu yang lama dan berkesinambungan (O. Candra, 2020). Khususnya daya tahan kardiovaskular (aerobik), yang diartikan sebagai kemampuan organisme tubuh terutama jantung, paru dan sistem peredaran darah dalam mengatasikelelahan (A. T. Candra \& Setiabudi, 2021). Salah satu cara untuk menilai daya tahan kardiorespirasi seseorang yaitu dengan mengukur nilai VO2max dengan tujuan mengukur kapasitas jantung, paru, dan darah untuk mengangkut oksigen ke otot yang bekerja dan mengukur penggunaan oksigen oleh otot (Nugraheni et al., 2017).

Tingkat VO2Max merupakan kemampuan individu untuk menghirup dan mengeluarkan oksigen dengan maksimal. Instrumen tes MFT (Multistage Fitness Test) dapat digunakan untuk mengetahui tingkat VO2Max seseorang. Kondisi VO2 max dapat dipakai sebagai parameter kebugaran jasmani seseorang (Nugroho, 2020). Setiaputri et al. (2017) berpendapat prestasi yang dicapai oleh atlet renang dipengaruhi oleh berbagai hal, salah satunya kebugaran jasmani.

Untuk mengetahui kondisi fisik seseorang terutama pada atlet, salah satu cara yang bisa digunakan adalah dengan mengetahui tingkat kemampuan dari beberapa komponen kondisi fisik tersebut. Persiapan kondisi fisik khusus dibangun atas dasar mempersiapkan atlet untuk menghadapi berbagai event. Tujuan utama dalam pembinaan kondisi fisik khusus adalah untuk memperdalam perkembangan unsur-unsur kondisi fisik yang lebih spesifik sesuai dengan tuntutan cabang olahraga (Amin \& Adnan, 2020). Kebutuhan kondisi fisik tersebut tidak dapat disamakan untuk masing-masing cabang olahraga, karena setiap cabang olahraga memiliki karakteristik gerak tersendiri (Wibisana et al., 2016). Oleh karena itu apabila seorang atlet ingin mencapai prestasi yang maksimal, maka faktor kondisi fisik secara bersamaanpun harus ditingkatkan (Syukur et al., 2019).

Ketika mempersiapkan atlet untuk ikut berpartisipasi dalam event olahraga seperti Pekan Olahraga Privinsi (PORPROV) 2022 maka para atlet renang PUSLATKOT Kota Kediri patut diketahui tingkat kondisi fisiknya. Kondisi fisik awal dapat digunakan sebagai tolok ukur pelatih atas kesiapan para atletnya untuk mengikuti ajang perlombaan tersebut. Berdasarkan pembahasan pentingnya tingkat kondisi fisik pada seorang atlet, maka pembahasan pada artikel ini kami fokuskan terhadap tingkat kekuatan otot tungkai dan daya tahan VO2Max atlet renang Puslatkot Koni Kediri.

\section{METODE}

Jenis penelitian ini merupakan deskriptif dengan pendekatan kuantitatif, dengan tujuan mengevaluasi serta menganalisis tingkat kondisi fisik para atlet PUSLATKOT cabang olahraga renang sebelum menghadapi event PORPROV 2022. Metode yang digunakan yaitu survei dengan teknik tes dan pengukuran. Untuk metode penentuan populasi ke sampel yaitu dengan menggunakan teknik total sampling. Sampel dalam penelitian ini adalah keseluruhan atlet PUSLATKOT cabang olahraga renang dengan jumlah 7 orang. Instrumen tes yang digunakan untuk mengetahui tingkat VO2Max adalah 
Jurnal Kejaora: Jurnal Kesehatan Jasmani dan Olah Raga

ISSN: 2541-5042 (Online)

ISSN: 2503-2976 (Print)

Volume 6 Nomor 1, Edisi April 2021

Multistage Fitness Tes (MFT) atau bleep test, sedangkan untuk mengetahui kekuatan otot tungkai dengan menggunakan tes vertical jump.

\begin{tabular}{llll}
\hline & & & $(\mathrm{BS})$ \\
\hline $60-72$ & 1 & 16,6 & Baik (B) \\
\hline $50-59$ & 1 & 16,6 & $\begin{array}{l}\text { Sedang } \\
(\mathrm{S})\end{array}$ \\
\hline $39-49$ & 4 & 66,6 & $\begin{array}{l}\text { Kurang } \\
(\text { K) }\end{array}$ \\
\hline$\leq$ & - & 0 & $\begin{array}{l}\text { Kurang } \\
\text { Sekali } \\
\text { (KS) }\end{array}$ \\
$\begin{array}{l}\text { Kebawa } \\
\mathrm{h}\end{array}$ & & & \\
\hline
\end{tabular}

Tabel diatas menunjukkan bahwa tingkat kondisi fisik kemampuan daya ledak otot tungkai atlet renang dengan jumlah responden 6 orang, masuk dalam kategori baik sekali sejumlah 0 atlet $(0 \%)$, kategori baik sejumlah 1 atlet $(16,6 \%)$, kategori sedang sejumlah 1 atlet $(16,6 \%)$, kategori kurang sejumlah 4 atlet $(66,6 \%)$ dan kurang sekali sejumlah 0 atlet (0\%).

Berikut ini merupakan tabel persentase tingkat VO2Max mengacu pada norma Brianmac.

Tabel 3.Norma Standarisasi Kemampuan VO2Max

\begin{tabular}{lll}
\hline No & Nilai & Kategori \\
\hline 1 & $\geq 52,4$ & Luar Biasa \\
\hline 2 & $46,5-52,4$ & Sangat Baik \\
\hline 3 & $42,5-46,4$ & Baik \\
\hline 4 & $36,5-42,4$ & Sedang \\
\hline 5 & $33,0-36,4$ & Kurang \\
\hline 6 & $\leq 33,0$ & Sangat Kurang \\
\hline
\end{tabular}

(Brianmac, n.d.)

Berdasarkan tabel norma standarisasi

Tabel 2. Deskripsi Persentase Klasifikasi Tes Vertical Jump

\begin{tabular}{|c|c|c|c|}
\hline $\begin{array}{l}\text { Jumlah } \\
\text { Nilai }\end{array}$ & $\begin{array}{l}\text { Frekuen } \\
\text { si }\end{array}$ & $\begin{array}{l}\text { Persentas } \\
\mathrm{e}(\%)\end{array}$ & $\begin{array}{l}\text { Klasifika } \\
\text { si }\end{array}$ \\
\hline$\geq 73$ & - & 0 & $\begin{array}{l}\text { Baik } \\
\text { Sekali }\end{array}$ \\
\hline
\end{tabular}
kemampuan VO2Max diatas, maka diperoleh deskripsi hasil analisis data dalam bentuk persentase pada tabel dibawah ini:

Tabel 4. Deskripsi Persentase Klasifikasi Tes VO2Max

\begin{tabular}{llll}
\hline Nilai & Frekuensi & $\begin{array}{l}\text { Persentase } \\
(\%)\end{array}$ & Kategori \\
\hline$\geq 52,4$ & - & 0 & Luar Biasa \\
\hline $46,5-52,4$ & 1 & 16,6 & Sangat Baik \\
\hline $42,5-46,4$ & 1 & 16,6 & Baik \\
\hline $36,5-42,4$ & 3 & 50 & Sedang \\
\hline $33,0-36,4$ & 1 & 16,6 & Kurang \\
\hline$\leq 33,0$ & - & 0 & Sangat Kurang \\
\hline
\end{tabular}


Jurnal Kejaora: Jurnal Kesehatan Jasmani dan Olah Raga

ISSN: 2541-5042 (Online)

ISSN: 2503-2976 (Print)

Volume 6 Nomor 1, Edisi April 2021

Dari tabel 3 dapat dijelaskan bahwa tingkat VO2Max atlet renang dengan total 6 atlet, masuk dalam kategori luar biasa sejumlah 0 atlet $(0 \%)$, kategori sangat baik sejumlah 1 atlet $(16,6 \%)$, kategori baik sejumlah 1 atlet $(16,6 \%)$, kategori sedang sejumlah 3 atlet $(50 \%)$, kategori kurang sejumlah 1 atlet $(16,6 \%)$ dan sangat kurang sejumlah 0 atlet $(0 \%)$.

Berdasarkan analisis data hasil kekuatan otot tungkai dengan menggunakan instrumen tes vertical jump pada atlet PUSLATKOT cabang olahraga renang, dapat dikemukakan bahwa prosentase terbesar berada dalam kategori kurang dengan persentase $66,6 \%$ sejumlah 4 atlet. Hal tersebut perlu menjadi sorotan dan perhatian lebih bagi pelatih, dikarenakan kemampuan daya ledak otot tungkai sangat dibutuhkan dalam cabang olahraga renang. Sebagaimana berdasarkan hasil penelitian (Syam \& Bismar, 2018) bahwa untuk memperoleh hasil yang optimal ketika renang gaya dada dibutuhkan kemampuan daya ledak tungkai, hal tersebut dikarenakan tungkai merupakan salah satu bagian dari struktur tubuh yang dibutuhkan dalam melakukan gerakan renang gaya dada. Terdapat beberapa gerakan dalam olahraga renang yang membutuhkan optimalisasi kekuatan otot tungkai, diantaranya adalah ketika seorang atlet melakukan gerakan awalan/start dan gerakan ketika mendorong air dengan menggunakan kaki. Oleh karena itu, untuk mempersiapkan atlet menghadapi event PORPROV 2022 maka pelatih diharapkan mampu memberikan sebuah program latihan yang berorientasi untuk meningkatkan kekuatan otot tungkai para atlet renang.

Berdasarkan analisis data hasil tingkat VO2Max dengan menggunakan instrumen tes MFT/bleep test pada atlet PUSLATKOT cabang olahraga renang, dapat dikemukakan bahwa prosentase terbesar berada dalam kategori sedang dengan persentase $50 \%$ sejumlah 3 atlet. Dalam dunia olahraga istilah VO2 max memang sudah tidak asing lagi. VO2 max merupakan daya tangkap aerobik maksimal, menggambarkan jumlah oksigen maksimum yang dikonsumsi per satuan waktu oleh

seseorang selama latihan atau tes, dengan latihan yang makin lama makin berat sampai kelelahan (Nugroho, 2020). Bahwa pada cabang olahraga renang, para atlet sangat membutuhkan tingkat volume oksigen yang cukup tinggi. Hal tersebut dikarenakan atlet dituntut untuk menunjukkan performanya secara baik dan tentunya dipengaruhi oleh tingkat volume oksigen yang dimiliki. Atlet yang memilikiVO2Max baik akan mampu tampil prima dengan kemampuan terbaiknya (Tumiwa et al., 2016). Sebagaimana pernyataan Nugroho (2020) seorang atlet yang memiliki VO2 max baik menunjukkan bahwa atlet tersebut memiliki daya tahan dan kebugaran yang baik. Oleh karena itu pelatih juga (Salman, 2018) harus menyusun sebuah program latihan yang spesifik untuk meningkatkan daya tahan fungsi jantung para atlet renang tersebut. Hal tersebut didukung oleh pernyataan dari Salman (2018) bahwa latihan daya tahan yang berguna melatih fungsi fisiologi jantung agar meningkatnya kapasitas oksigen dalam paru-paru.

\section{KESIMPULAN}

Berdasarkan hasil dan pembahasan yang telah dipaparkan maka dapat disimpulkan bahwa prosentase vertical jump terbesar berada dalam kategori kurang dengan persentase $66,6 \%$ sejumlah 4 atlet. Sedangkan prosentase terbesar tingkat VO2Max berada dalam kategori sedang dengan persentase $50 \%$ dengan jumlah 3 atlet.

\section{DAFTAR PUSTAKA}

Amin, H., \& Adnan, A. (2020). Studi Tentang Beberapa Komponen Kondisi Fisik Atlet Bolavoli SMK Negeri 1 Kota Solok. Jurnal Patriot, 2(1), 265-276.

Brianmac. (n.d.). Pengaruh interval training terhadap vo2max atlet ukm gulat universitas negeri surabaya lazoardy zola septian. Retrieved April 7, 2021, from http://brianmac.co.uk/beep:htm

Candra, A. T. (2016). Studi Tentang Kemampuan Lompat Tegak Siswa Sekolah Dasar Negeri Berdasarkan Perbedaan Geografis Sebagai 
Jurnal Kejaora: Jurnal Kesehatan Jasmani dan Olah Raga

ISSN: 2541-5042 (Online)

ISSN: 2503-2976 (Print)

Volume 6 Nomor 1, Edisi April 2021

Identifikasi Bakat Olahraga. Jurnal SPORTIF, 2(2), 1-14.

Candra, A. T., \& Setiabudi, M. A. (2021). Analisis Tingkat Volume Oksigen Maksimal ( VO 2 Max ) Camaba Prodi PJKR. Jurnal Peendidikan Kesehatan Rekreasi, 7(1), 10-17.

Candra, O. (2020). Tingkat Kemampuan VO2Max Pada Atlet Bola Basket Puteri POMNAS Riau. Journal Sport Area, 5(2), 106-115.

Haryono, S., \& Pribadi, F. S. (2012). Pengembangan Jump Power Meter Sebagai Alat Pengukur Power Tungkai. Jurnal Media IImu Keolahragaan Indonesia, 2(1).

Junaidi, S. (2019). Metode Latihan Bermain Untuk Meningkatkan Power Otot Tungkai Atlet Bolavoli Pada Tim Pervik Kediri Tahun 2018. Journal of Sport and Exercise Science, 2(1).

Kemendiknas. (2010). VO2Max.

Lufisanto, M. S. (2014). Analisis Kondisi Fisik Yang Memberi Kontribusi Terhadap Tendangan Jarak Jauh Pada Pemain Sepakbola. Jurnal Kesehatan Olahraga, 03(01).

Mulyadi, H., \& Nikon, B. (2019). Tinjauan Kondisi Fisik Atlet Bola Basket. Jurnal Pendidikan Jasmani Dan Olahraga, 2(2), 26-32.

Musrifin, A. Y., \& Bausad, A. A. (2020). Analisis Unsur Kondisi Fisik Pemain Sepak Bola Mataram Soccer Akademi NTB. Jurnal IImiah Mandala Education, 6(1), 113-119.

Nugraheni, H. D., Marijo, \& Indraswari, D. A. (2017). Perbedaan Nilai VO2Max Antara Atlet Cabang Olahraga Permainan Dan Bela Diri. Jurnal Kedokteran Diponegoro, 6(2), 622631.

Nugroho, W. (2020). Profil Tingkat Volume Oksigen Maksimal Pada Atlet Puslatda PON XX Daerah Istimewa Yogyakarta. Majalah IImiah Olahraga (MAJORA), 26(1), 27-32.

Pengaruh Metode Latihan dan Kekuatan Otot Tungkai Terhadap Power Otot Tungkai. (, April). http://www.brianmac.co.uk.

Pramudani, A. H., Kumaidah, E., \& Hardian. (2018). Pengaruh Latihan Skipping Terhadap Vertical Jump Mahasiswa Fakultas Kedokteran Universitas Diponegoro. Jurnal Kedokteran Diponegoro, 7(4), 1755-1762.

Salman, E. (2018). Kontribusi VO2Max Terhadap Kemampuan Renang Gaya Dada 200 Meter. Jurnal Pendidikan Jasmani Dan Olahraga, 1(2), 21-31.

Setiaputri, K. A., Rahfiludin, M. Z., \& Suroto. (2017). Hubungan Konsumsi Zat Gizi, Persentase Lemak Tubuh Dan Aktivitas Fisik Dengan Kebugaran Jasmani Pada Atlet Renang. Jurnal Kesehatan Masyarakat, 5(3).

Supriyoko, A., \& Mahardika, W. (2018). Kondisi Fisik Atlet Anggar Kota Surakarta. In Jurnal Sportif (Vol. 4, Issue 2).

Syam, N., \& Bismar, A. R. (2018). Hubungan Daya Ledak Tungkai Dan Kekuatan Otot Lengan Terhadap Kemampuan Renang Gaya Dada Pada Atlet Renang PR. Garuda Laut Makasaar. Jurnal Pendidikan Kepelatihan Olahraga, 10(2).

Syukur, M. R., Budiarto, \& Kastrena, E. (2019). Kontribusi Daya Ledak Otot Lengan dan Daya Ledak Otot Tungkai Terhadap Hasil Smash. Jurnal Maenpo, 09(1), 23-29.

Tumiwa, H. T., Rattu, A. J. M., \& Paul A T Kawatu. (2016). GAMBARAN KAPASITAS VITAL PARU DAN VOLUME OKSIGEN MAKSIMUM ( VO2MAX ) PADA ATLET SEPAK BOLA PS . BANK sulutgo di Kota Manado tahun 2016. Jurnal IImiah Farmasi, 5(2), 251-258.

Utami, D. (2015). Peran Fisiologi Dalam Meningkatkan Prestasi Olahraga Indonesia Menuju Sea Games. Jurnal Olahraga Prestasi, 11(2), 52-63.

Wibisana, F., Rinaldy, A., \& Nusufi, M. (2016). Evaluasi Kondisi Fisik Dominan Pada Atlet Karate-DO DOJO Lanal INKAI Kota Sabang Tahun 2015. Jurnal IImiah Mahasiswa Pendidikan Jasmani, Kesehatan Dan Rekreasi, 2(1), 82-89. 
Jurnal Kejaora: Jurnal Kesehatan Jasmani dan Olah Raga

ISSN: 2541-5042 (Online)

ISSN: 2503-2976 (Print)

Volume 6 Nomor 1, Edisi April 2021

Widyaratni, A. A. I. F., Wahyuni, N., Muliarta,

I. M., \& Nurmawan, I. P. S. (2016).

Penambahan Contrax Relax

Stretching Lebih Efektif Daripada

Ballistic Stretching Pada Latihan

Depth Jump Terhadap Peningkatan

Vertical Jump Atlet Basket Sma

(Slua) Saraswati 1 Denpasar. Majalah IImiah Fisioterapi Indonesia, 3(1).

Wiwoho, H. A., Junaidi, S., \& Sugiarto. (2014). Profil Kondisi Fisik Siswa Ekstrakurikuler Bola Basket Putra SMA N 02 Ungaran Tahun 2012. Journal Of Sport Sciences and Fitness, 3(1), 44-48. 